\title{
СЛОВНИК С. АДАЛЬБЕРГА ЯК ПІДГРУНТЯ ВИОКРЕМЛЕННЯ ГАЛИЦЬКИХ ФРАЗЕОЛОГІЧНИХ ПОЛОНІЗМІВ (НА МАТЕРІАЛІ ГАЛИЦЬКО-РУСЬКИХ НАРОДНИХ ПРИПОВІДОК, УКЛАДЕНИХ І. ФРАНКОМ)
}

\author{
ОЛЬГА ПРАСОЛ \\ Харківський національний педагогічний університет ім. Г. С. Сковороди, \\ Харків - Україна
}

\section{SŁOWNIK SAMUELA ADALBERGA JAKO PODSTAWA DLA WYRÓŻNIENIA GALICYJSKICH POLONIZMÓW FRAZEOLOGICZNYCH (NA MATERIALE GALICYJSKO-RUSKICH PRZYPOWIEŚCI LUDOWYCH IWANA FRANKI) \\ OLGA PRASOK \\ Charkowski Narodowy Uniwersytet Pedagogiczny im. H. Skoworody, Charków — Ukraina}

STRESZCZENIE. W artykule rozpatrywany jest wpływ słownika Księga przysłów przypowieści i wyrażeń przysłowiowych polskich S. Adalberga na kształtowanie się paremicznej i frazeologicznej koncepcji I. Franki, obecnej już w procesie układania jego Galicyjsko-ruskich przypowieści ludowych. Stwierdza się, iż na podstawie słownika S. Adalberga sformował się system frazeologicznych, leksykalnych i leksyko-semantycznych polonizmów w składzie paremii umieszczonych w Galicyjsko-ruskich przypowieściach ludowych.

\section{SAMUEL ADALBERG'S DICTIONARY AS A BASIS OF SINGLING \\ OUT GALICIAN PHRASEOLOGICAL POLONISMS \\ (ON THE MATERIAL OF IVAN FRANKO'S \\ GALICIAN-RUTHENIAN FOLK PROVERBS)}

\section{OLGA PRASOL}

H. S. Skovoroda Kharkiv National Pedagogical University, Kharkiv — Ukraine

ABSTRACT. The given article explores how the dictionary "Księga przysłów przypowieści i wyrażeń przysłowiowych polskich" by Samuel Adalberg influenced the formation of Ivan Franko's paroemial and phraseographic conception that was mostly implemented in the process of compiling Galician-Ruthenian Folk Proverbs. It emphasizes that Samuel Adalberg's dictionary became the starting point for the creation of phraseological polonisms system as well as for lexical and lexical-semantic polonisms as part of paroemial units reflected in Galician-Ruthenian Folk Proverbs.

I

сторична доля склалася так, що галицька і польська лінгвокультури співіснували в різних сферах національної культури, і цей факт відбився на розвитку української літературної мови. Однак немає такої сфери поширення мови, де б галицька мовна практика не залишила свого сліду, про що переконливо писали насамперед О. Горбач і Ю. Шевельов. Названий процес можна простежи- 
ти й на паремійних зразках, що були запозичені тим чи тим шляхом 3 польської мови в українську. Спробуємо репрезентувати цю проблему на прикладі аналізу Галищько-руських народних приповідок ${ }^{l}$, укладених і потрактованих Іваном Франком, що до цього часу не досліджувалися з огляду на виокремлення власне полонізмів. Ідеться про запозичення паремій цілком чи використання полонізмів у репрезентованих одиницях словника. Власне паремію I. Франко розумів дуже широко, адже в його часи пареміології як науки не існувало й не існувало проблеми вузького й широкого розуміння обсягу фразеології. Український письменник увів у паремійний словник не лише прислів'я, приказки, фразеологізми, скоромовки, штампи окремих мовленнєвих жанрів, як-от: вітальні формули, формули співчуття, компліменту, висловлення жалю, ущипливості й под., але й деякі прецедентні тексти, зокрема кінцівки анекдотів, пісень і т. ін.

Відомо, що в процесі підготовки свого словника I. Франко активно використовував словник С. Адальберга Księga przystów przypowieści i wyrażeń przysłowiowych polskich ${ }^{2}$, але, наскільки цей словник вплинув на формування пареміологічної й фразеографічної концепції І. Франка, до цього часу до кінця невідомо.

Мета цієї наукової розвідки — описати вплив пареміологічної і фразеографічної концепції С. Адальберга на формування лінгвістичного світогляду I. Франка, роль названого словника для розвитку польської й української пареміографії, а також з'ясувати, наскільки словник С. Адальберга вплинув на поповнення складу одиниць Галищько-руських народних приповідок, укладених I. Франком, якими способами відбувався цей процес і як I. Франко оцінював словник С. Адальберга.

Проблемі іншомовних запозичень і процесам їхнього засвоєння було присвячено чимало наукових розвідок, зокрема й таких метрів науки, як І. Білодід, I. Огієнко, О. Потебня, С. Смаль-Стоцький та ін. Полонізми як явище української мови й мовлення активно досліджували також такі мовознавці сучасності, як М. Беднаж, Д. Будняк, Л. Гонтарук, Й. Дзендзелівський, М. Демський, І. Кононенко, В. Піддубна таін. Фразеологічніполонізми в сучасній лінгвістиці найбільш послідовно досліджують І. Кононенко, А. Кравчук, Г. Крайчинська, Ю. Сагата, Л. Ткач. Перший в історії української й польської науки Українсько-польський фразеологічний словничок уклав колектив кафедри україністики Познанського університету імені Адама Міцкевича під керівництвом проф. Т. Космеди. Цей словничок є додатком до підручника Українська фразеологія для польських студентів $^{3}$ і містить близько 800 одиниць. Його найбільше достоїнство полягає в тому, що це, власне, перший словник подібного типу. Звичайно, він невеликий за обсягом, спрощений у словникових примітках, не відтворює відповідної параметризації, що характерно для академічних словників, але цього не вимагає жанр навчальної літератури. $С$ потреба його розширити й зокрема, як видається, включити в його склад паремійні одиниці, що функціонують у Галицькоруських народних приповідках, укладених І. Франком.

I. Франко зібрав величезний приповідковий матеріал, записуючи його „3 уст народу”, залучаючи різні друковані й рукописні джерела. Він „пояснив

${ }^{1}$ Галицькко-руські народні приповідки у 3-x m., зібрав, упоряд. і пояснив др. Іван Франко, 2-е вид., Львів 2006, т. 1-3 — далі поклик на це джерело подаємо в круглих дужках у тексті статті із використанням скорочення ГРНП, після якого подаємо вказівку на том і конкретну сторінку.

${ }^{2} \mathrm{~S}$. A dalb erg, Księga przystów przypowieści i wyrażeń przysłowiowych, Warszawa 1889-1894, s. 805.

3 Т. Космеда, Т. Осіпова, М. Четирба, Л. Малецький, О. Ерделі, Українська фразеологія: теорія, вправи, тести, словник (для студентів української філології); за наук. ред. Т. Кос меди, Познань 2011, 204 с. 
первинні й вторинні значення більшості зафіксованих ним прислів 'їв, навів паралелі з інших слов'янських та ряду неслов'янських мов"4.

У процесі створення Галищько-руських народних приповідок I. Франко звертався до національних та європейських здобутків у галузі пареміології, зокрема праць В. Вісловського, Г. Ількевича, М. Номиса, П. Чубинського, М. Валя, К. Вандера, О. Кольберга, Й. Галлера, К. Крумбахера, С. Франкена, Г. Фрішбіpa, Л. Чапінського, А. Цінціале, А. Затурецького, Я. Люблінського, Ф. Челаковського, В. Даля, М. Дикарєва, П. Симоні, А. Гільфердінга, Е. Муки, І. Носовича, П. Славейкова.

Серед найавторитетніших праць, провідні ідеї яких було покладено в основу збірки, як зауважувалося, Księga przystów przypowieści i wyrażeń przystowiowych polskich Самуїла Адальберга. С. Адальберг працював над своєю збіркою з 1883 до 1894 року. Польський дослідник підійшов до пареміології як до самостійної наукової дисципліни. Як писав названий дослідник, ані польська, ані зарубіжна література не мали праці, що ввібрала б усі книжкові джерела в певну систему.

Його збірка містить близько 5100 головних виразів, тобто окремих статей, що налічують майже 30000 паремій, не враховуючи варіантів. Увесь матеріал Книги поділяється на два великі розділи. Перший складається з уже охопленого друком матеріалу (усі видані до того часу спеціальні збірки паремій, етнографічні праці, виписки, зроблені з творів найвидатніших письменників XVI, XVII, XVIII ст.). Другий розділ складають матеріали, що ще не були надруковані.

С. Адальберг намагався уникати помилок, які допускали його попередники, насамперед уключення чужих прислів 'їв у збірки польських прислів 'їв, намагався залишити тільки ті одиниці, що мали чіткі ознаки паремій, хоч це йому, як видається, не завжди вдавалося, оскільки не була напрацьована відповідна теорія щодо розуміння паремій. Виписував їх із доступних на той час дуже скромних джерел.

Згодом С. Адальбергу пощастило познайомитися з I. Берштейном, який надав йому можливість користування своєю приватною бібліотекою, що налічувала понад 2000 екземплярів книг саме з пареміями.

С. Адальберг опрацьовував стародруки, рукописи Я. Пшибильського, Т. Ліпінського та ін. Не залишав поза увагою й усі діалектні прислів'я з різних регіонів (сілезькі, пруські, мазурські, кашубські тощо). Під час фіксації паремій із різних друкованих джерел зазначений пареміограф керувався основним принципом - подавати їх без жодних скорочень та переробок, навіть зберігаючи всі архаїчні мовні ознаки, лише зі зміною орфографії. Біля кожної паремії, ії варіанта або цитати із старопольських письменників автор збірки подавав у скороченні джерела, з яких їх було взято.

Закцентуємо увагу й на концепції Книги, методиці ії укладання. До моменту появи цієї праці, як стверджував сам автор розглядуваного джерела, не існувало системи впорядкування й укладання паремійних збірок: опис усіх концептуальних засад цього процесу залишався в рукописі. Як приклад розуміння алфавітного розміщення паремійного матеріалу в словнику наведено міркування С. Яховича. Звичайно, в найбільших збірках паремій, виданих до кінця XVIII ст., зустрічається виключно алфавітний порядок укладання за першою літерою абетки. Однак уже на той час стало зрозумілим, що така система була найменш зручною для використання.

${ }^{4}$ М. М. Пазяк, Украӥнські прислів'я та приказки. Проблеми пареміології та пареміографiï, Київ 1964, с. 8. 
С. Адальберг запропонував нову алфавітно-гаслову систему укладання паремій, що полегшила користування цим матеріалом. Завдання укладача збірки паремій С. Адальберг порівнював із завданням бібліотекаря, „ідеалом якого $\epsilon$ розміщення книжок у такий спосіб, щоб пошукувану книжку вдалося віднайти якнайшвидше, без жодних труднощів”5. Запроваджений у книзі „Предметний покажчик”, містить близько 40000 посилань і дає змогу легко віднайти паремії, пов'язані з головним виразом. У “Передмові”" до словника зазначається, що усі прислів’я, зосереджені під певним головним виразом, розміщені в алфавітному порядку за першою буквою кожної паремії й пронумеровані. Якщо певна паремія мала кілька варіантів, то найстарший із них подано на початку великим друком й позначений цифрою, а за ним уже в хронологічному порядку (меншим шрифтом) усі інші ${ }^{6}$ С. Адальберг наводить короткі, але вичерпні пояснення щодо вживання паремії, іiї появи й історії, щодо архаїзмів, діалектизмів тощо, іноді вдаючись до зіставлення інформації із більш ранніх джерел. У Книзі можна простежити історію виникнення та використання паремій, отримати інформацію, в яких збірках вони містяться і в яких записані вперше, які варіанти має кожна конкретна паремія, які давні автори вживали іiї до чи після охоплення відповідної паремійної одиниці даною збіркою.

Отже, Книга С. Адальберга є неоціненним і багатим надбанням як конкретно для слов’янської, так і європейської пареміології загалом. Цю працю брали за основу А. Брюкнер, який 1895 р. видав збірку Przysłowia, kartki z dziejów literatury i kultury polskiej, як продовження роботи С. Адальберга з'явилася фундаментальна праця Ю. Кшижановського - чотиритомна збірка Nowa ksiega przystów i wyrażeń przysłowiowych polskich (1969-1978).

I. Франко високо цінував паремійну збірку С. Адальберга, мабуть, тому він так часто звертався до неї й використовував для укладання Галицьько-руських народних приповідок, наводячи польські паралелі, залучаючи джерельну базу цього словника, оскільки „хотів показати, яким є відсоток українських оригінальних приповідок, а скільки взято від великоросів, білорусів та поляків...”7.

Наведемо приклади кількох словникових статей, де I. Франко звертається до згаданої вище збірки польського пареміографа. Це він робив з метою:

1) порівняння значення української паремії 3 польським еквівалентом, напр.: Добра баба до поради. Жіноча ремонстрация супроти чоловічого: йди геть, що ти мені поможеш! Зовсім інше значінє має споріднена з сею приповідка у Поляків (Adalb. Baba 93): Porade do baby, a przez niq do czarta, себто: хіба чорт може дати гіршу раду, як баба (ГРНП-т.1, с. 39); 3 батов би і біда кінияя не урвала. "Біда" в значіню чорта; "кінця урвати" — дійти до ладу. У Поляків простіше: Z baba czart nie poradzi (Adalb. Baba 37) (ГРНП-т.1, с. 40);

2) пошуку способу пояснення паремій при виникненні певних труднощів, напр.: Маєш бабо редути! Редути - масковий баль. Оповіданя, яке дало, очевидно, почин тій приповідці, про нещасні пригоди баби на масковім балі, я не чув. Приповідка первісно польська, вживаєся, коли кому несподівано трафиться якась прикрість або перешкода. Adalb. Baba 68: Masz babo redutę! — також не пояснено (ГРНП-т. 1, с. 41); Як біда, то до Жида, а як мине біда, най дідько бере Жида. Жид у селі звичайно - шинкарь, у якого люде заливають своє горе горівкою. Розуміється, що коли мине потреба такого хвилевого забутя, звичай-

\footnotetext{
${ }^{5}$ S. Adalberg, Ksiega przysłów przypowieści i wyrażeń przysłowiowych, Warszawa 1889-1894, s. 13.

${ }^{6}$ Там само, с. 15.

${ }^{7}$ І. Я. Франко, Лист до М. П. Драгоманова від 4 грудня 1883 р., [в:] його ж, Зібрання творів у 50 m., Київ 1986, т. 48, с. 383-384.
} 
ний чоловік до коршми не йде тай супроти Жида не почуваєся до ніякої вдячности. Близша до нашої польська припов. Kiedy bieda, to do Żyda, a po biedzie za drzwi Żydzie! (Adalb. Bieda 57), хоча тут очевидно характеризуєся положенє і настрій польського пана, що в біді позичає від Жида гроші, а потім знов поводиться з Жидом як із собакою (ГРНП-т.1, с. 92);

3) пояснення параметрів уживання, подання стилістичних приміток, напр.: Біда учить хліба. Еліптично зам. добувати хліба. Троха інакше, жартливо у Поляків: Nauczy bieda pierogów jeść (Adalb. Bieda 112) (ГРНП-т.1, с. 77);

4) пояснення походження польських та українських приповідок, напр.: Haучит біда попити, коли ся нема чого вхопити. Натяк на бідний стан давніх попів, що жили з ласки громади. Значінє: біда примушує чоловіка промишляти, про себе, давати собі раду, щоб не терпіти голоду. Дословно з руського перекладено у Поляків: Nauczy bieda popić, kiedy niema czego chopić (Adalb. Bieda 74). (ГРНП-т.1, с. 85); Кожний блазен свойм стройом. Кожний чоловік має в собі дозу дурноти. Взято з поль. Adalb. Błazen 12 (ГРНП-т.1, с. 102).

Однак I. Франко іноді не погоджується з С. Адальбергом і шукає пояснення окремих слів у інших словниках, напр.: Вдячний як баран. Мабуть іронія; баран штовхає й того, хто дає йому їсти, пор. польське (з іншим вістрєм): I maly baran często czabana wybodzie (Adalb. Baran 11). Варто завважити, що Адальберг поясняє: „czaban - gatunek większych baranów”, хоч у словнику Лінде міг знайти властиве поясненє: великий віл, або пастух-волар (ГРНП-т.1, с. 52).

Інколи I. Франко заперечує подане С. Адальбергом пояснення, напр.: A біло?Біло. А чорно? Чорно. Характеризують чоловіка, що без власної думки притакує всьому, що чув від інших. Те саме у Поляків (Adalb. Biało 1). Рей поясняє (та мабуть не сю приказку, хоч Адальберг приточує сюди його поясненє): Co ma być biało, niechajże będzie biało; a co ma być brudno, niechaj będzie brudno, a złego nigdy nie chwalić, a dobrego nie ganić. Се поясненє належить радше до дальшого ч. 4 або до якоїсь подібної приповідки (ГРНП-т.1, с. 97).

I. Франко, як і С. Адальберг, розглядав паремійний склад мови широко, дещо ширше, ніж розуміють його сучасні пареміологи при широкому підході до їхнього трактування. На його думку, як і на думку С. Адальберга, це „не тільки моральні, філософські судження, життєві правила, але також певні стереотипні особисті рефлексії, вислови загальнолюдських почувань, прокляття, жарти, ущипливості, висміювання, порівняння і фігуральні звороти, як і деякі, якщо можна так сказати, вивітрені формули ворожби — „примовлянь”, $<\ldots>$ найрізноманітніші пародії (молитов, обрядів, заклять і навіть серйозних прислів”їв) < .. >, деякі ,застарілі” загадки, значення яких стало з часом настільки прозорим, що народ перестав уважати їх загадками і вживає як прислів'я"» .

Українська мова, зважаючи на ії контакти з іншими національними мовами, що пов'язано з політичними, культурними та економічними взаємозв'язками з відповідними народами, запозичила певні мовні елементи, що були їй потрібні для гармонійного розвитку. Досліджуючи цей процес, Л. Ткач зокрема наголошує, що „позитивний бік цього процесу полягав не лише в засвоєнні українською мовою нових понять, а й в активізації пошуків найбільш відповідних до системи української мови питомих засобів ії̈ вираження. Взаємодія з чужими мовами створювала відповідне тло, на якому було чіткіше усвідомлено само-

83 фольклористичної спадщини Івана Франка. Недрукована передмова до збірки прислів”їв, підготовка до друку, переклад і вступна замітка О. І. Дея, [в:] „Народна творчість та етнографія”, 1963, № 2, с. 94. 
бутні ознаки української мови, а також підтримувало ті мовні паралелі, в яких збережено давні риси української мови, відтворювані місцевими діалектами"9 .

M. Демський також схарактеризував процес запозичення в межах не української літературної мови загалом, а окремих її діалектів, що, звичайно, згодом певним чином впливає й на розвиток української літературної мови, оскільки запозичення потрапляють у літературну мову й через діалекти, порівн.: „Для частини бойківських фразем дериваційною базою послужили іншомовні фраземи. Творення фраземи на базі чужомовного матеріалу в сучасному мовознавстві трактується як запозичення, а сам процес переходу з однієї мови в іншу як системна транспозиція. Щоправда, одні мовознавці запозиченнями вважають лише ті фраземи, що прийшли в мову ззовні і вживаються в ній у тому вигляді, в якому вони відомі чи були відомі в мові-джерелі (скажемо відразу, що такого роду запозичень на території бойківського ареалу немає), інші — i ті, що запозичені без змін, i ті, що певним чином адаптовані мовою, яка запозичує. Сам процес адаптації, як й у разі з лексикою, трактується як калькування. Серед адаптованих чужомовних фразем розрізняють точні кальки, тобто такі фраземи, що без будь-яких відхилень відтворюють лексико-граматичний склад чужої фраземи, та неточні, чи такі, в яких допущено певні відхилення в лексикограматичній передачі окремих компонентів (саме таких фразем-кальок найбільше в бойківських говірках). 3 чужомовних фразем у ролі дериваційних баз для бойківських фразем найчастіше виступають польські"10 .

Високо оцінював процес запозичення, насамперед з польської мови, й I. Франко, всебічно використавши для фіксації й інтерпретації подібних запозичень і словник С. Адальберга Księga przysłów przypowieści i wyrażeń przysłowiowych polskich, про що йшлося в цій науковій студії. У процесі використання зазначеного словника, як бачимо, I. Франко насамперед ставив два основних завдання - виявити польсько-галицькі відповідники, що функціонували на Галичині напр. XIX - на поч. XX ст., і з'ясувати загалом специфіку польського впливу на формування галицько-руських приповідок, які І. Франко зібрав.

Крім того, він проаналізував пареміологічну концепцію С. Адальберга й перейняв найбільш прийнятне для власної концепції побудови паремійного словника, зокрема систематичний розподіл паремій за опорними словами (опорногаслова система класифікації), розміщення приповідкових одиниць за алфавітом для зручності користування матеріалом. Ф. Колесса писав: „За прикладом Вандера та Адальберга дав і Франко порядкове нумерування приповідок під кожною темою, а при тому порядкове нумерування всієї колекції, що йде в живій пагінації на версі кожної сторінки, що влекшує цитування й вишукування потрібних приказок... Франків збірник приповідок у порівнянні з іншими визначається ще й тому, що він прикладав велику увагу до географічного розміщення"11.

Отже, І. Франко збагатив теорію і практику української пареміографії, перейнявши досвід С. Адальберга й талановито розвинувши його ідеї, проте виокремивши й деякі недоліки, що цілком слушно з огляду на поступовий характер науки загалом.

Перспективу дослідження вбачаємо в необхідності повного й послідовного аналізу словника паремій, укладеного Іваном Франком, для виокремлення відповідних типів запозичень з урахуванням прагматики усталених виразів.

9 Л. О. Ткач, Українська літературна мова на Буковині в кіниі XIX-на початку XX cm., ч. 1., Матеріали до словника, Чернівці 2000, с. 11.

${ }^{10}$ М. Т. Демський, Дериваційна база діалектної фраземи з бойківського ареалу, [в:] Українська діалектна лексика, за ред. І. Г. Матвіяса, Київ 1987, с. 58.

${ }^{11}$ Ф. Колес са, Іван Франко, [в:] “Дзвін”, 2006, ч. 8, с. 93. 